Scientia Marina 77(1)

March 2013, 61-68, Barcelona (Spain)

ISSN: 0214-8358

doi: $10.3989 /$ scimar.03707.07A

\title{
Endoparasites of Trachurus picturatus (Pisces: Carangidae) from the Madeira and Canary Islands: Selecting parasites for use as tags
}

\author{
GRAÇA COSTA ${ }^{1,2}$, MARIA TERESA GARCIA SANTAMARIA ${ }^{3}$, \\ JOANA VASCONCELOS ${ }^{1}$, CLARA BORGES PERERA ${ }^{3}$ \\ and EGBERTO MELO-MOREIRA ${ }^{1}$
}

\footnotetext{
${ }^{1}$ Estação de Biologia Marinha do Funchal, Universidade da Madeira, Promenade Orla Marítima do Funchal, 9000-107 Funchal, Portugal. E-mail: gcosta@uma.pt

${ }^{2}$ ISOPlexis, Universidade da Madeira,Campus da Penteada, 9000-390, Funchal, Portugal.

${ }^{3}$ IEO, Instituto Español de Oceanografia, Calle General Gutiérrez 4, 38003 Santa Cruz de Tenerife, España.
}

\begin{abstract}
SUMMARY: In order to evaluate the use of parasites as biological tags to identify populations of the oceanic horse mackerel, Trachurus picturatus, two samples of 100 fish each, caught off the Madeira and Canary Islands from January to June 2009, were examined for the presence of anisakids, trypanorhynchs, acanthocephalans and liver coccidians. In T. picturatus from Madeira, prevalence of the coccidian Goussia cruciata reached 82\%, whereas prevalence of the nematode Anisakis sp., the acanthocephalan Rhadinorhynchus cadenati and the trypanorhynch Nybelinia lingualis were $12.0 \%, 8.9 \%$ and $7.0 \%$, respectively. In samples from the Canary Islands, prevalence of G. cruciata was 8.0\%, Anisakis sp. and R. cadenati reached $5.0 \%$ and $42.0 \%$ respectively, and $N$. lingualis was not recovered. The absence of $N$. lingualis and the lower prevalence of Anisakis sp. appear to be related to the smaller size of the oceanic horse mackerels examined from the Canary Islands. Although significant differences in prevalence of two parasites, G. cruciata and R. cadenati, were found between the two regions investigated $\left(\chi^{2}=125.13, \mathrm{df}=1, \mathrm{p}=0.000\right.$ and $\left.\chi^{2}=40.77, \mathrm{df}=1, \mathrm{p}=0.000\right)$, only . cruciata was considered useful as a biological tag for the identification of populations of T. picturatus. In order to reach sound conclusions, an expansion of the temporal and spatial sampling strategy is recommended.
\end{abstract}

Keywords: parasites, biological tags, Trachurus picturatus, Madeira Islands, Canary Islands.

RESUMEN: Endoparásitos de Trachurus picturatus (Pisces: CARANGidae) de Madeira e Islas Canarias: selección para su USO COMO MARCADORES BIOLÓGICOS. - Con objeto de evaluar el uso de parásitos como marcadores biológicos para identificar las poblaciones del chicharro, Trachurus picturatus, se analizaron dos muestras de 100 ejemplares capturados en Madeira y en las Islas Canarias, desde enero hasta junio de 2009, para determinar la presencia de anisákidos, trypanorhyncha, acantocéfalos y coccidios en el hígado. En T. picturatus de Madeira, el coccidio Goussia cruciata alcanzó un $82 \%$ de prevalencia, mientras que el nemátodo Anisakis sp., el acantocéfalo Rhadinorhynchus cadenati y el trypanorhyncha Nybelinia lingualis el $12.0 \%$, $8.9 \%$ y $7.0 \%$, respectivamente. La ausencia de $N$. lingualis y la escasa presencia de Anisakis sp en los ejemplares procedentes de las Islas Canarias podrían estar relacionadas con el menor tamaño de los ejemplares analizados. Aunque se hallaron diferencias significativas en la presencia de $G$. cruciata y $R$. cadenati entre las dos regiones estudiadas $\left(\chi^{2}=125.13, \mathrm{df}=1\right.$, $\mathrm{p}=0.000$ y $\chi^{2}=40.77, \mathrm{df}=1, \mathrm{p}=0.000$ ), sólo $G$. cruciata fue considerado como marcador biológico útil para la identificación de poblaciones de T. picturatus. Se recomienda una ampliación espacio-temporal del muestreo con el fin de obtener conclusiones definitivas.

Palabras clave: parásitos, marcadores biológicos, Trachurus picturatus, Madeira, Islas Canarias. 


\section{INTRODUCTION}

Several studies have examined the parasite composition of commercially exploited fish species in distinct geographical regions with the aim of identifying different fish populations or stocks (MacKenzie 1990, George-Nascimento and Arancibia 1992, Williams et al. 1992, MacKenzie et al. 2008, Santos et al. 2009). Two different approaches have been recognized by a number of researchers for the use of parasites as indicators of fish population structure: one using a small number of parasite species (Sindermann 1957, MacKenzie 1985, Lang et al. 1990, Abaunza et al. 1995) and one using entire parasite assemblages (GeorgeNascimento 2000, Timi 2003, Brickle and MacKenzie 2007, MacKenzie et al. 2008, Henriquez et al. 2011). Because small pelagic fishes have lower parasite species richness, the first approach has been favoured in the study of population structuring in small pelagic fishes (Sindermann 1957, Reimer 1978, MacKenzie 1990, Abaunza et al. 1995).

The oceanic horse mackerel, Trachurus picturatus (Bowdich, 1825) (Pisces: Carangidae) is a small benthopelagic fish species that is commercially exploited in the Macaronesian region of the Azores, Madeira and Canary Islands. Its geographical range extends from the Mediterranean to the eastern central North Atlantic in neritic zones and island shelves, banks and seamounts (Smith-Vaniz 1986). According to Shaboneyev and Ryazantseva (1977), there appeared to be differences in growth parameters and morphological characteristics between T. picturatus from the Azores and Canary Islands. Data obtained by Gouveia (1993) on the biology of this fish species suggested differences between populations of the Azores and Madeira Islands based on morphological characteristics.

Parasite species richness of this fish species was studied in the Azores Archipelago and Western Sahara Atlantic region (Gaevskaya and Kovaleva 1980, 1985) and in the Madeira Archipelago (Gonçalves 1996, Costa et al. 2012), evidencing regional differences in prevalence and intensity of some helminth parasites, which could indicate the existence of different populations of this fish species. Here we report the occurrence of some internal parasites of the oceanic horse mackerel from two geographic regions, the Madeira Islands and the Canary Islands, and discuss the feasibility of using two horse mackerel specific parasites, a protozoan apicomplexan and an acanthocephalan, as biological tags for the identification of populations of T. picturatus.

\section{MATERIALS AND METHODS}

Samples of oceanic horse mackerel, T. picturatus, were obtained from commercial fish landings at the Madeira Islands $\left(33^{\circ} 7^{\prime} 30^{\prime} ' \mathrm{~N}, 16^{\circ} 16^{\prime} 30^{\prime}\right.$ ' $\mathrm{W}$ ) and $\mathrm{Ca}-$ nary Islands $\left(28^{\circ} 16^{\prime} 7^{\prime}\right.$ ' $\mathrm{N}, 16^{\circ} 36^{\prime} 20^{\prime}$ 'W) from January to March 2009 (first sampling period) and April to June 2009 (second sampling period) (Fig. 1). Additionally,

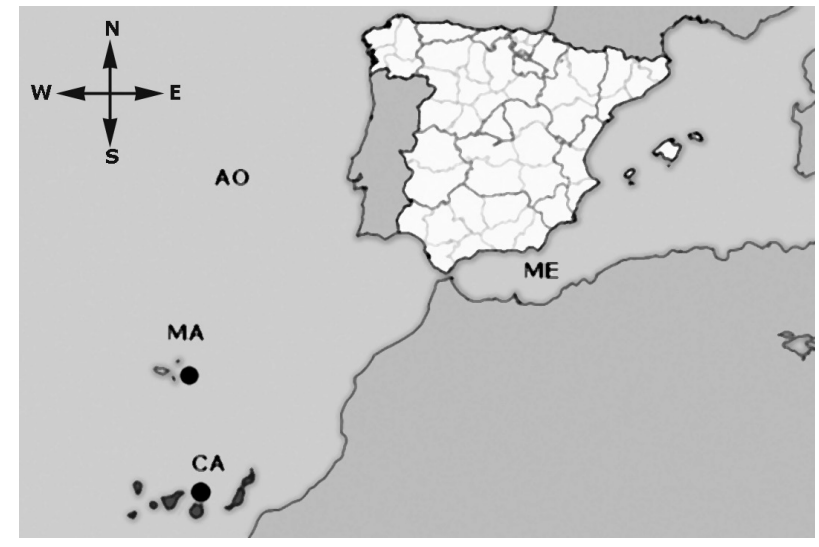

FIG. 1. - Map of the central North Atlantic (AO) showing sampling locations (black circles) at the Madeira Islands (MA) and Canary Islands (CA). (ME) Mediterranean Sea.

samples of oceanic horse mackerel from the Canary Islands were obtained in September and November 2009 (third sampling period) with the purpose of determining the life span of acanthocephalans.

After total fish length had been recorded in centimetres $(\mathrm{cm})$, fish were kept deep frozen at $-17^{\circ} \mathrm{C}$, until parasitological examination was possible. Initially the intention was to analyse all parasites (ecto and endoparasites). However, since fish were kept frozen for several months prior to examination, monogeneans and digeneans would be adversely affected. Therefore, it was decided to concentrate the analysis on coccidians, acanthocephalans, larval trypanorhynchs and anisakid nematodes of the digestive tract and body cavity, which can still be studied after prolonged freezing. Fresh squash preparations of liver were examined unstained for the presence of coccidians, using a Zeiss Axioplan Photomicroscope equipped with DIC optics and an MC-Camera. Stomach and intestine were dissected and examined for the presence of helminths, using a Stemi 2000 binocular stereomicroscope. The body cavity was examined for the presence of larvae of helminth parasites.

Liver coccidians were identified according to Lom and Dyková (1992). Recovered helminths were preserved in either $70 \%$ or $95 \%$ ethanol. Those in $70 \%$ ethanol were cleared in lactophenol or in glycerine, mounted in glycerine jelly and identified according to Golvan (1969) for acanthocephalans, Palm (2004) for larval trypanorhynchs, and Berland (1961) for nematodes. Prevalence $(\mathrm{P}$, number of fish infected divided by the number of examined fish), mean intensity (total number of parasites of a particular taxon found divided by the number of infected fish), abundance (A, number of individuals of a particular parasite in a single infected or uninfected host) and mean abundance (total number of parasites of a particular taxon found divided by the total number of fish examined) were calculated according to Bush et al. (1997). Intensity (I, number of individuals of a particular parasite species in a single infected host) of infection with coccidians was evalu- 
ated using a semi-quantitative method, on the basis of number of oocysts seen in a single squash from individual livers, rated as 1 (low) when fewer than 10 oocysts were seen, 2 when fewer than 50 oocysts were seen, 3 when 50-100 oocysts were seen and 4 (heavy) when more than 100 oocysts were seen in the liver smear.

Relationships between fish length and mean abundance of parasites were analysed with the Spearman's correlation coefficient. Differences in the abundance of parasites between sampling periods were examined with the Mann-Whitney U test (Fowler et al. 1998). Significance of prevalence differences between regions was studied with the chi-square test. Differences in fish length between sampling periods and regions were evaluated with the Mann-Whitney U test because the data were non-normal (Kolmogorov-Smirnov and Shapiro Wilk tests). Statistical analysis was performed with SPSS 11.0. The aggregation indices, variance/ mean ratio $\left(s^{2} / x\right)$ and index of dispersion $(D)$ of Poulin (1993) were calculated using the program QP 3.0 (Rozsá et al. 2000).

\section{RESULTS}

\section{Length and diet data of examined Trachurus picturatus}

Two hundred $T$. picturatus were examined, 100 from the Madeira Islands, ranging in length from 16.20 to $30.40(20.95 \pm 3.58$; mean \pm sd), and 100 from the Canary Islands, with lengths from 13.50 to $22.50 \mathrm{~cm}$ (18.52 \pm 1.94$)$, from January to June 2009. Significant differences in fish length were found between the two sampled regions, the smallest fish being caught in the Canary Islands (Mann-Whitney $\mathrm{U}=2900.5, \mathrm{z}=-5.13$, $\mathrm{p}=0.000$ ). In each region, significant differences in fish length were also found between sampling periods,
TABLE 1. - Total body length $(\mathrm{cm})$ of the oceanic horse mackerel, Trachurus picturatus, examined from two geographical regions, the Madeira Islands and the Canary Islands, in the first (JanuaryMarch), second (April-June) and third (September-November) sampling periods.

\begin{tabular}{|c|c|c|c|}
\hline \multicolumn{2}{|c|}{ Geographical region } & \multirow{2}{*}{$\begin{array}{l}\text { Mean length } \pm \text { SD } \\
\text { (min.-max.) } \\
\text { April-June }\end{array}$} & \multirow[b]{2}{*}{ Sept-Nov } \\
\hline & Jan-March & & \\
\hline s & $\begin{array}{r}19.2 \\
(16.2\end{array}$ & $\begin{array}{r}22.7 \\
(17.1\end{array}$ & - \\
\hline Can & $\begin{array}{c}20.24 \pm 0.73 \\
(19.10-22.30)\end{array}$ & $\begin{array}{c}16.81 \pm 1.04 \\
(13.70-18.60)\end{array}$ & $\begin{array}{c}17.28 \pm 1.39 \\
(14.40-20.0)\end{array}$ \\
\hline
\end{tabular}

with bigger fish found in the second sampling period (April to June) in the Madeira Islands, whereas in the Canary Islands smaller fish were found in the second sampling period (Mann-Whitney, $\mathrm{z}=-2.20, \mathrm{p}=0.03$ and $\mathrm{z}=-8.62, \mathrm{p}=0.000$, respectively) (Table 1). Stomach contents of fish sampled from the Canary Islands in the second sampling period contained mostly isopods and some remains of small fishes, whereas in the first and third sampling periods the stomachs were filled with remains of small fishes. Stomach contents of fish sampled from the Madeira Islands consisted of remains of fishes and euphausiids.

\section{Goussia cruciata}

Oocysts of Goussia cruciata ((Thélohan, 1894) Labbé, 1896), with sporocysts characteristically arranged forming a cross, were seen in livers of oceanic horse mackerel. Numbers of oocysts in the livers of $T$. picturatus from the Madeira Islands were higher than those found in fish from the Canary Islands. On a scale of 1 to 4 (low to heavy intensity of infection), $26.0 \%$ of livers of fish from the Madeira Islands reached intensity level 4 , followed by $30.0 \%$ with intensity level 3 and $31.0 \%$ with intensity levels 1 and 2 . Overall prevalence of $G$. cruciata in fish from the Madeira

TABLE 2. - Prevalence (P), mean intensity (MI) and mean abundance (MA) of parasites, with range in brackets, found infecting Trachurus picturatus from the Madeira Islands and the Canary Islands in the first (January-March) and second (April-June) sampling periods. (A) Adult stages; (L) larval stages.

\begin{tabular}{|c|c|c|c|c|c|c|}
\hline Parasite species & $\mathrm{P}(\%)$ & $\begin{array}{c}\text { adeira Islan } \\
\text { MI }\end{array}$ & MA & $\mathrm{P}$ & $\begin{array}{c}\text { Canary Islands } \\
\text { MI }\end{array}$ & MA \\
\hline \multicolumn{7}{|l|}{ Goussia cruciata } \\
\hline January-March & 100 & - & - & 16.0 & - & - \\
\hline April-June & 71.10 & & & 0.0 & & \\
\hline Total prevalence & 82.0 & & & 8.0 & & \\
\hline \multicolumn{7}{|c|}{ Rhadinorhynchus cadenati (A) } \\
\hline January-March & 0 & 0 & 0 & 0 & 0 & 0 \\
\hline April-June & 8.90 & $3.25(1-5)$ & $0.29(0-5)$ & 84.0 & $18.74(1-148)$ & $15.74(0-148)$ \\
\hline Total prevalence & 4.0 & & & 42.0 & & \\
\hline \multicolumn{7}{|l|}{ Anisakis sp. (L) } \\
\hline January-March & 3.6 & 1 & 0.04 & 6.0 & 1.67 & 0.10 \\
\hline April-June & 22.2 & $5.9(1-15)$ & $1.31(0-15)$ & 4.0 & 1.0 & 0.04 \\
\hline Total prevalence & 12.0 & & & 5.0 & & \\
\hline \multicolumn{7}{|c|}{ Nybelinia lingualis $(\mathrm{L})$} \\
\hline January-March & 10.90 & $1.67(1-3)$ & $0.18(0-3)$ & 0 & - & - \\
\hline April-June & 2.20 & 1.0 & 0.02 & 0 & - & - \\
\hline Total prevalence & 7.0 & & & 0 & & \\
\hline
\end{tabular}



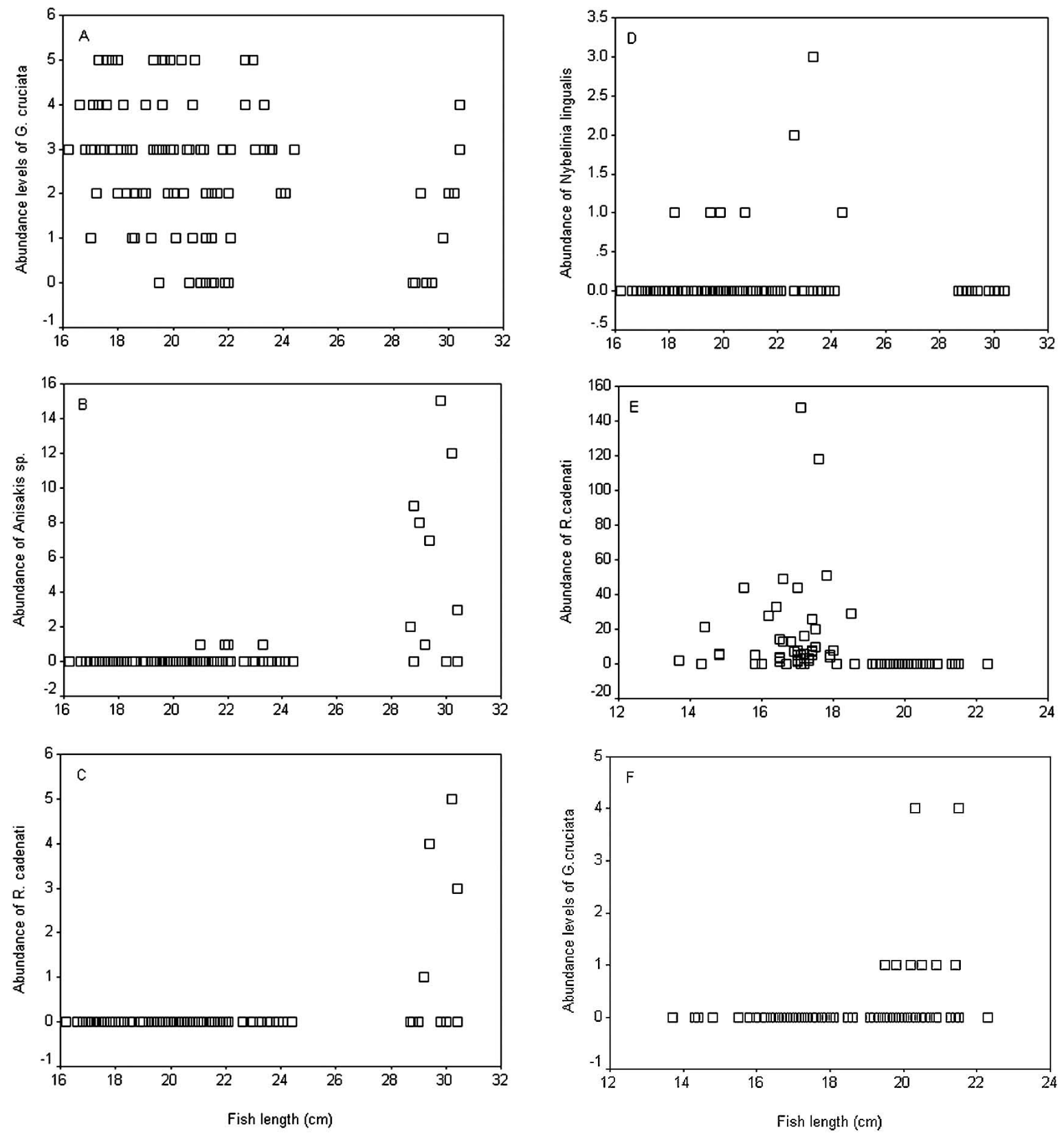

FIG. 2. - Abundance of endoparasites of T. picturatus, in relation to fish length, at the Madeira Islands: (A) G. cruciata, (B) Anisakis sp., (C) $R$. cadenati, (D) N. lingualis and at the Canary Islands: (E) R. cadenati, (F) G. cruciata.

Islands was $87.0 \%$, with variation from $100 \%$ in the first sampling period (January to March) to $71.10 \%$ in the second sampling period (April to June). In fish from the Canary Islands, on the other hand, prevalence was $16.0 \%$ in the first sampling period, whereas no infected fish were found in the second sampling period. Intensity level 1 represented $6.0 \%$ and intensity level 4 represented $2.0 \%$ (Table 2). A significant negative correlation was found between fish length and mean abundance of G. cruciata in oceanic horse mackerel from the Madeira Islands $(r=-0.33, p=0.001)$. Significant differences in prevalence of this coccidian were found between the Madeira and Canary Islands $\left(\chi^{2}=125.13\right.$, $\mathrm{df}=1, \mathrm{p}=0.000$ ).

\section{Rhadinorhynchus cadenati}

A total of 787 individuals of Rhadinorhynchus cadenati (Golvan et Houin, 1964) were found in the intestines of fish from the Canary Islands and 13 individuals only were recovered from the intestines of fish from the Madeira Islands. Aggregation indices, variance/mean ratio $\left(s^{2} / x\right)$ and index of discrepancy (D) for R. cadenati, recovered from T. picturatus from 
TABLE 3. - Prevalence (\%) of Goussia cruciata and Rhadinorhynchus cadenati in relation to fish length at the Madeira and Canary Islands in two seasons of the year. (R) R. cadenati; (G) Goussia cruciata.

\begin{tabular}{lcccc}
\hline \multirow{2}{*}{ Length class $(\mathrm{cm})$} & \multicolumn{2}{c}{ Madeira Islands } & \multicolumn{2}{c}{ Canary Islands } \\
\hline $13-18$ & $62.9(\mathrm{n}=35)^{*}(\mathrm{G})$ & $46.1(\mathrm{n}=115)^{*}(\mathrm{G})$ & Spring & $0.0(\mathrm{G})$ \\
& $0.0(\mathrm{R})$ & $0.0(\mathrm{R})$ & no data & $84.0(\mathrm{R})$ \\
$19-22$ & $81.4(\mathrm{G})$ & $77.3(\mathrm{G})$ & $16.0(\mathrm{G})$ & no data \\
and $\geq 22$ (only Madeira) & $0.0(\mathrm{R})$ & $18.2(\mathrm{R})$ & $0.0(\mathrm{R})$ & no data \\
& & & Summer & \\
\hline
\end{tabular}

* Data from 1996: Spring (March-April); Summer (May-June); Winter (January-February). At the Madeira Islands 43 fish in spring, 22 in summer and 35 in winter; at the Canary Islands 50 in spring and 50 in June. Winter values are not shown because there were no fish samples from the Canary Islands in winter.

the Canary Islands, suggested that the distribution of this acanthocephalan is overdispersed $\left(\chi^{2}=18.05\right.$, $\left.\mathrm{df}=12, \mathrm{p}=0.05 ; s^{2} / x=56.77 ; D=0.84\right)$. While overall prevalence reached only $4.0 \%$ at the Madeira Islands, $42.0 \%$ of fish were infected at the Canary Islands. Infections with this parasite were mostly found in the second sampling period ( $\mathrm{P}=84.0 \%, \mathrm{n}=50$; see Table 2 ). Significant differences were found in the prevalence of $R$. cadenati between the Madeira and Canary Islands $\left(\chi^{2}=40.77, \mathrm{df}=1, \mathrm{p}=0.000\right)$. A negative significant correlation was observed between mean abundance and length for $R$. cadenati in the Canary Islands $(\mathrm{r}=-0.69$, $\mathrm{p}=0.000)$. All infected fish were found in the second sampling period, so the factor most influencing the mean abundance of this parasite could be sampling period rather than length $(\mathrm{U}=200.00, \mathrm{z}=-8.07, \mathrm{p}=0.000$, $\mathrm{r}=-0.81)$. At the Madeira Islands, on the other hand, the sampling period effect on the mean abundance of $R$. cadenat was weaker $(\mathrm{U}=1150.00, \mathrm{z}=-2.03, \mathrm{p}=0.04$, $\mathrm{r}=-0.20)$. However, only 4 fish were infected with a maximum of 5 parasites, so the significance of this conclusion is not statistically strong. At the Canary Islands, 42 fish were infected, so the significance of the statistical results is more robust. An additional sample of 50 fish, from September $(n=30)$ and November 2009 $(n=20)$ composed of fish ranging in length from 14.40 to $20.0 \mathrm{~cm}(17.28 \pm 1.39)$ aimed to establish the timing of infection with $R$. cadenati and its life span, in order to further evaluate the validity of this parasite as a tag. Although fish were still found infected with $R$. cadenati in September $(\mathrm{p}=33.30 \%)$, mean intensity (1.30) and mean abundance values $(0.43)$ were much lower than those found in June, and no infections were found in November 2009.

\section{Larval stages of Anisakis sp. and Nybelinia lingualis}

Sixty-one larval L3 stages of Anisakis sp. (Dujardin, 1845 ) were found in the visceral cavity of $T$. picturatus from the Madeira Islands and 7 in oceanic horse mackerel from the Canary Islands. Prevalence reached $12.0 \%$ in the Madeira Islands and $5.0 \%$ in the Canary Islands (Table 2). Ten larval stages of Nybelinia lingualis (Cuvier, 1817) were found in 7 oceanic horse mackerel from the Madeira Islands only $(\mathrm{P}=7.0 \%)$. Aggregation indices, variance/mean ratio $\left(s^{2} / x\right)$ and index of discrepancy $(D)$ for Anisakis sp. suggested an overdispersed distribution $\left(\chi^{2}=3.73, \mathrm{df}=5, \mathrm{p}=0.05 ; s^{2} /\right.$ $x=8.70 ; D=0.93)$. Fish length was positively correlated with the mean abundance of Anisakis sp. in the Madeira Islands only $(r=0.48 ; p=0.000)$.

Table 2 shows mean intensity and mean abundance values of the helminth taxa Anisakis sp., $N$. lingualis and $R$. cadenati, as well as the prevalence of both helminths and the coccidian parasite. The abundance of the parasites in relation to fish length for T. picturatus caught at the Madeira and Canary Islands are represented in Figure 2.

\section{DISCUSSION}

Previous surveys of parasites of $T$. picturatus (and T. trachurus) suggested that some of their endohelminth parasites, such as digeneans, were unsuitable to be used as biological tags for stock identification due to their short life span and low prevalence of infection (Gaevskaya and Kovaleva 1985, MacKenzie et al. 2008, Costa et al. 2012). Other parasites with promising roles in elucidating aspects of the population biology and migrations of $T$. picturatus included larval cestodes, acanthocephalans and G. cruciata (see Gaevskaya and Kovaleva 1985, Costa et al. 2012).

\section{Goussia cruciata}

Goussia cruciata is known to infect the livers of members of the genus Trachurus, namely T. trachurus, $T$. mediterraneus and $T$. picturatus, from the Mediterranean and the Atlantic Ocean (Kalfa-Papaioannou and Athanassopoulou-Raptopoulou 1984, Daoudi 1987, Gonçalves 1996, Diouf et al. 2000, Abollo et al. 2001, MacKenzie et al. 2008). Our results showed that $G$. cruciata is very common at the Madeira Islands, as previously described by Gonçalves (1996), who also reported the presence of this parasite all year round, and even infecting small fishes of $12 \mathrm{~cm}$ length. On the other hand G. cruciata is less common in the Canary Islands (Table 2). It was not found on the banks of the Azores Archipelago (Irving and Meteor banks) or in the Western Sahara, specifically in $T$. picturatus, but it was found in other Trachurus species from off West Africa (see Table 3) (Gaevskaya and Kovaleva 1980, 1985, Diouf et al. 2000, MacKenzie et al. 2008). 
Differences in prevalence of this coccidian have been reported previously, with higher prevalence around the Iberian Peninsula and in the central Mediterranean than in the western Mediterranean and the Canary Islands (Kalfa-Papaioannou and Athanassopoulou-Raptopoulou 1984, Daoudi 1987, MacKenzie et al. 2008). As in the present results, variations in the prevalence of this coccidian suggested a relationship with sampling period rather than with fish length, with higher prevalence in the winter-spring period in comparison with summer (Gonçalves 1996, MacKenzie et al. 2008). When the values of the prevalence and intensity of infection data of this coccidian at the Madeira and Canary Islands in the present survey are compared, the differences found cannot be attributed to sampling period, as fish from these two regions were caught at the same time of the year.

Although there were significant differences in the fish length between the two regions, previous results have concluded that prevalence was not related to host length (Gonçalves 1996, MacKenzie et al. 2008). It appears that the southern boundary for this parasite is located at the Madeira Islands, with some infected fish in the Canary Islands due to migration of fish from the Madeira Islands to Canary Islands, or from the Mediterranean, where G. cruciata is common in Trachurus species.

\section{Rhadinorhynchus cadenati}

Differences were also found in the prevalence and mean abundance of $R$. cadenati, a parasite known to be common in Trachurus species off West Africa and the Azores Islands (Golvan 1969, Gaevskaya and Kovaleva 1985 , MacKenzie et al. 2008). Our results suggested that prevalence and mean abundance of $R$. cadenati is not entirely length-related as was previously thought (MacKenzie et al. 2008), but rather is more dependent on the sampling period, with fish of different lengths being infected in the second sampling period but not in the first (see Table 3).

Previous studies of the parasites infecting T. picturatus conducted at the Madeira Islands concluded that $R$. cadenati was absent in fish of less than $20 \mathrm{~cm}$ length, in three seasons of the year (winter, spring and summer, see Gonçalves 1996). By contrast, at the Canary Islands $R$. cadenati infected fish of less than 20 $\mathrm{cm}$. The infection with this parasite is possibly due to isopods, which are known to be intermediate hosts of acanthocephalans and filled the stomachs of the fish caught in June 2009, thus explaining the higher infections with $R$. cadenati in this region. However, in September, and in particular in November, feeding shifted mainly to fishes, as was demonstrated by the presence of fish scales in the stomachs leading to a lower infection and complete absence of $R$. cadenati in September and November 2009, respectively.

It appears that infection takes place in late spring and that the life span of this parasite is not more than
6 months, decreasing its value as a biological tag for population identification. Nevertheless, it could still be used as an indicator of migratory behaviour of $T$. picturatus. Since infection with this parasite probably occurs in late spring, the observed decrease in the infection levels in September and November 2009 could be due to either immigration of fish from the Madeira Islands to the Canary Islands or emigration of infected fish from the Canary Islands to the Madeira Islands during the autumn period. These results indicate some degree of mixing of T. picturatus between the Madeira and Canary Islands, with the area of infection with $R$. cadenati located in the Canary Islands, within the known endemic area of this parasite (Gaevskaya and Kovaleva 1985, MacKenzie et al. 2008).

\section{Larval stages of Anisakis sp. and N. lingualis}

Larval Anisakis sp. and N. lingualis could not be considered effective biological tags, as present and previous data on the infection of $T$. picturatus and other Trachurus species infected with these parasites determined that their prevalence and mean abundance were length-dependent, with fish of less than $21 \mathrm{~cm}$ showing low prevalence of infection (MacKenzie et al. 2008, Costa et al. 2012).

\section{Importance of diet for parasite transmission}

An earlier study of the feeding habits of T. picturatus along the shelf region of the northwestern Atlantic African coast concluded that mysids and euphausiids were not common in the zooplankton samples, and that the diet of fish of less than $25 \mathrm{~cm}$ consisted mostly of copepods and malacostracan larvae (Isopoda) (Kompowski 1976). This finding is in agreement with the higher prevalence of infection with $R$. cadenati found in our Canary Islands samples, which consisted of fish less than $25 \mathrm{~cm}$ in length.

In contrast, fish of the $25-$ to $30-\mathrm{cm}$ length class feed predominantly on euphausiids and fishes, and to a lesser extent on malacostracan larvae, which may explain the higher prevalence of anisakids and the very low prevalence of $R$. cadenati at the Madeira Islands in the second sampling period, when some fish of that length class $(n=11)$ were concurrently more infected with Anisakis sp.

Nevertheless, fish from different regions may have different parasites as a result of the availability or lack of suitable intermediate hosts in their diet (Marcogliese 1995, 2002), so one should be careful in the choice of the parasites as biological tags and in the conclusions drawn from parasitological surveys (Lester and MacKenzie 2009).

\section{CONCLUSIONS}

Although two parasites, R. cadenati and G. cruciata, showed significantly different prevalence in the 
two study areas, only G. cruciata could fulfil most of the criteria for the first approach of the usefulness of parasites as biological tags, namely a long life span in the host, significant levels of infection (prevalence) between the study areas in different sampling periods, and a level of infection that was fairly constant from year to year and was easily detected and identified (MacKenzie and Abaunza 1998, MacKenzie et al. 2005).

Expanding the temporal and spatial sampling strategy to include other geographical areas such as the Mediterranean and the Iberian Peninsula, and examining more samples in all seasons of the year, would be appropriate in order to add further information on the biology of this species throughout its complete distributional range, and to determine the relationships between the different geographic areas in terms of occurrence of parasites.

\section{ACKNOWLEDGEMENTS}

Funding for the present study was partially provided by the Portuguese Foundation for Science and Technology (FCT/POCTI) through multi-year programmes. Fish samples from the Madeira Islands were kindly provided by the Regional Fisheries Department (DRP/DSIP Funchal). Special thanks are due to Dr. Ken MacKenzie of the University of Aberdeen for reading and improving an earlier version of the present manuscript. We also thank the reviewers for their comments, which helped to improve this manuscript.

\section{REFERENCES}

Abaunza P., Villamor B., Pérez J.R. 1995. Infestation by larvae of Anisakis simplex (Nematoda: Ascaridata) in horse mackerel Trachurus trachurus and Atlantic mackerel Scomber scombrus in ICES division VIIIb, VIIIc, and IXa (N-NW Spain). Sci. Mar. 59: 223-233.

Abollo E., Calvo M., Pascual S. 2001. Hepatic coccidiosis of the blue whiting, Micromesistius poutassou (Risso) and the horse mackerel, Trachurus trachurus (L.) from Galician waters. J. Fish Dis. 24: 335-343.

Berland B. 1961. Nematodes from some Norwegian marine fishes. Sarsia 2: 1-50

Brickle P., MacKenzie K. 2007. Parasites as biological tags for the Falklands mullet (Teleostei:Eleginopidae). J. Helminthol. 81: 147-153.

Bush A.O., Lafferty K.D., Lotz J.M., Shostak A.W. 1997. Parasitology meets ecology on its own terms: Margolis et al revisited. J Parasitol. 83: 575-583.

Costa G., Melo-Moreira E., Pinheiro de Carvalho M.A.A. 2012. Helminth parasites of the oceanic horse mackerel Trachurus picturatus Bowdich 1825 (Pisces: Carangidae) from Madeira Island, Atlantic Ocean, Portugal. J. Helminthol. 86: 368-372.

Daoudi F. 1987. Coccidies et coccidioses de poisons mediterranée ns: systemátique, ultratructure et biologie. $\mathrm{PhD}$ thesis, Univ. Montpellier, Montpellier, 302 pp.

Diouf M., Benajiba M.H., Senhaji M. 2000. Goussia cruciata (Thélohan, 1892) a hepatic coccidian parasite of horse mackerel Trachurus trachurus (Linnaeus, 1758) from the Mediterranean coasts of northern Morocco. Bull. Eur. Fish Pathol. 20: 219-223.

Fowler J., Cohen L., Jarvis P. 1998. Practical statistics for field biology. John Wiley \& Sons, Chichester, 259 pp.

Gaevskaya A.V., Kovaleva A.A. 1980. The use of parasitological data in population studies on Atlantic Carangidae of the genus Trachurus. Konf. Ukrainskoeo Parazitol. Obshch. Tezisy
Doklavov Chast'1 Kiev 9: 132-133 (in Russian, translated to English by Dennis M).

Gaevskaya A.V., Kovaleva A.A. 1985. The parasite fauna of the oceanic horse mackerel Trachurus picturatus picturatus and eco-geographical characteristics of its formation. Ehkol. Morya 20: 80-84 (In Russian, translated to English by Dennis M).

George-Nascimento M., Arancibia H. 1992. Stocks ecológicos del jurel (Trachurus symmetricus murphyi Nichols) en tres zonas de pesca frente a Chile, detectados mediante comparación de su fauna parasitaria y morfometria. Rev. Chil. Hist. Nat. 65: 453-470.

George-Nascimento M. 2000. Geographical variations in the jack mackerel Trachurus symmetricus murphyi populations in the southeastern Pacific Ocean as evidenced from the associated parasite communities. J. Parasitol. 86: 929-932.

Golvan Y.J. 1969. Systematic des Acanthocéphales. L'ordre des Palaeacanthocephala Meyer 1931. Mém. Mus. Natl. Hist. Nat. sér. A Zool. 57: 1-373.

Gonçalves M.C.B. 1996. Parasitas internos do chicharro Trachurus picturatus (Bowdich 1825) da Madeira: Histopatologia e prevalência. Dipl. thesis, Univ. Madeira, Funchal, 41 pp.

Gouveia M.E.P. 1993. Aspectos da biologia do chicharro, Trachurus picturatus (Bowdich, 1825) da Madeira. Dipl. thesis, Univ. Lisboa, Lisboa, 153 pp.

Henriquez V.P., Gonzalez M.T., Licandeo R., Carvajal J. 2011. Metazoan parasite communities of rock cod Eleginops maclovinus along southern Chilean coast and their use as biological tags at a local spatial scale. J. Fish Biol. 79: 1851-1865.

Kalfa-Papaioannou A.M., Athanassopoulou-Raptopoulou F. 1984. Incidence of coccidiosis in horse-mackerel (Trachurus trachurus, T. mediterraneus, T. picturatus) and sardines (Clupea pilchardus) from the North Aegean Sea. Zbl. Vet. Med. B 31: 530-536.

Kompowski A. 1976. A study of the food and feeding habits of Trachurus trachurus, T. trecae, T. picturatus and Caranx rhonchus in the region of Cape Blanc. Acta Ichthyol. Piscat. 6: 35-57.

Lang T., Damm U., Weber W., Neudecker T., Kuhlmorgen-Hille G. 1990. Infestation of herring (Clupea harengus L.) with Anisakis sp. larvae in the western Baltic. Arch. Fischereiwiss. 40: 101-117.

Lester R.J.G., MacKenzie K. 2009. The use and abuse of parasites as stock markers for fish. Fish. Res. 97: 1-2.

Lom J., Dyková I. 1992. Protozoan parasites of fishes. Developments in Aquaculture and Fisheries Science, Elsevier Science Publishers BV, Amsterdam, 315 pp.

MacKenzie K. 1985. The use of parasites as biological tags in population studies of herring (Clupea harengus L.) in the North Sea and to the north and west of Scotland. J. Cons. int. Explor. Mer 42: 33-64.

MacKenzie K. 1990. Cestode parasites as biological tags for mackerel (Scomber scombrus L.) in the northeast Atlantic. J. Cons. int. Explor. Mer 46: 155-166.

MacKenzie K. 2002. Parasites as biological tags in population studies of marine organisms: an update. Parasitol. 124: 153-163.

MacKenzie K., Abaunza P. 1998. Parasites as biological tags for stock discrimination of marine fish: a guide to procedures and methods. Fish. Res. 38: 45-56.

MacKenzie K., Campbell N., Mattiucci S., Ramos P., Pinto A.L., Abaunza P. 2008. Parasites as biological tags for stock identification of the Atlantic horse mackerel Trachurus trachurus L. Fish. Res. 89: 136-145.

Marcogliese D.J. 1995. The role of zooplankton in the transmission of helminth parasites of fish. Rev. Fish. Biol. Fish. 5: 336-371.

Marcogliese D.J. 2002. Food webs and parasite transmission. Parasitol. 124: S83-S99.

Palm H.W. 2004. The Trypanorhyncha Diesing, 1863. PKSPL-IPB Press, Bogor, $710 \mathrm{pp}$.

Poulin R. 1993. The disparity between observed and uniform distributions: a new look at parasite aggregation. Int. J. Parasitol. 23: $937-944$.

Reimer L.W. 1978. Monogenean trematodes as biological tags for sprat in the North Sea. ICOPA IV, section H: 6-7.

Rozsá L., Reiczigel J., Majoros G. 2000. Quantifying parasites in samples of hosts. J. Parasitol. 86: 228-232.

Santos M.J., Saraiva A., Cruz C., Eiras J.C., Hermida M., Ventura C., Soares J.P. 2009. Use of parasites as biological tags in stock identification of the black scabbardfish, Aphanopus carbo 
Lowe, 1839 (Osteichthyes: Trichiuridae) from Portuguese waters. Sci. Mar. 73S2: 55-62.

Shaboneyev I.E., Ryazantseva E.I. 1977. The structure of a population of the oceanic horse mackerel Trachurus picturatus picturatus (Bowdich) Vopr. Ikhtiologii. 17: 1127-1131.

Sindermann C.J. 1957. Diseases of fishes of the western North Atlantic. V. Parasites as indicators of herring movements. Maine Department of Sea and shore. Fish. Bull. 27: 1-30.

Smith-Vaniz W.F. 1986. Carangidae. In: Whitehead P.J.P, Bauchot M.L., Hureau J.C., Nielsen J., Tortonese E. (eds), Fishes of the north-eastern Atlantic and the Mediterranean. UNESCO, pp. 815-844.
Timi J.T. 2003. Parasites of Argentine anchovy in the south-west Atlantic: latitudinal patterns and their use for discrimination of host populations. J. Fish Biol. 63: 90-107.

Williams H.H., MacKenzie K., McCarthy A.M. 1992. Parasites as biological indicators of the population biology, migration, diet and phylogenetics of fish. Rev. Fish Biol. Fish. 2: 144-176.

Scient. ed.: A. Guerra.

Received August 9, 2012. Accepted January 17, 2013.

Published online February 7, 2013 